\title{
Bulukumba di Tengah Pergolakan DI/TII 1952-1965
}

\author{
Widia Astuti Ansar, Ahmadin, M. Rasyid Ridha \\ Pendidikan Sejarah FIS UNM \\ widiaansar28@gmail.com
}

\begin{abstract}
Abstrak
Tulisan ini mengkaji tentang latar belakang keberadaan gerakan DI/TII di Bulukumba, aktivitas gerakan DI/TII, serta dampak keberadaan gerakan DI/TII terhadap masyarakat Bulukumba selama kurun waktu 1952-1965. Hasil penelitian menunjukkan keberadaan gerakan DI/TII di Bulukumba didukung oleh keadaan geografis daerah Bulukumba yang sebagian besar wilayah perbukitan dan hutan-hutan yang lebat. Kondisi demografis dengan penduduk mayoritas Islam serta adanya kekerabatan yang kuat antara masyarakat dan DI/TII yang menjadi faktor keberadaan gerakan DI/TII di wilayah tersebut. Dalam penelitian ini turut disajikan pula faktor bergabungnya masyarakat Bulukumba dalam gerakan DI/TII pimpinan Kahar Muzakkar. Selama keberadaannya, berbagai aktivitas dilakukan antara lain penculikan, perampokan di darat dan di laut, pembakaran rumah-rumah penduduk, sarana dan prasarana pemerintahan, serta aksi sabotase berupa perusakan jembatan, penebangan pohon-pohon, penggalian jalanan untuk menghambat mobilitas TNI yang merupakan "musuh" dari DI/TII. Dampak keberadaan gerakan DI/TII di Bulukumba menimbulkan lumpuhnya perputaran ekonomi karena tertutupnya akses antara "kota dan desa", pendidikan tidak berjalan baik karena sebagain besar guru-guru dan murid-murid sekolah diculik oleh gerombolan DI/TII, adanya penghapusan strata sosial dan kegiatan-kegiatan yang menyimpang dari ajaran agama Islam. Metode yang digunakan dalam penelitian ini yakni metode penelitian sejarah dengan melalui 4 tahapan yaitu: heuristik, kritik, interpretasi, dan historiografi. Heuristik merupakan kegiatan pengumpulan sumber sejarah yang berkaitan dengan topik yang dibahas melalui penelitian pustaka dan wawancara. Kritik sumber berupa kritik ekstern dan kritik intern guna mendapatkan data yang otentik. Kemudian tahap interpretasi atau pemberian makna terhadap data yang diperoleh hingga dapat disusun menjadi fakta-fakta sejarah yang kemudian ditulis menjadi karya sejarah yang disusun secara kronologis.
\end{abstract}

\section{Kata Kunci : DI/TII, Bulukumba, Pergolakan}

\begin{abstract}
This paper discusses the background of the DI/TII in Bulukumba, the activity of the DI/TII, as well as the impact of the existence of the DI/TII to the community Bulukumba for a period of 1952-1965. The results showed the existence of the DI/TII in Bulukumba be supported by the state of the geographical area Bulukumba the part of the hills and forests so thick. The demographic with the majority of the Islamic and are strong among the public and DI/TII the factors the existence of the DI/TII in the region. In this study were presented also factor in the Bulukumba in motion DI/TII the leadership of the Kahar Muzakkar. During its existence, a variety of activities be done, among others, kidnapping, robbery on the ground and at sea, the burning of the people's houses, facilities and infrastructure of government, as well as acts of sabotage in the form of the destruction of the bridge, felling trees, digging the road to hamper the mobility which is "enemy" of DI/TII. The impact of the DI/TII in Bulukumba to its velocity of the economy because the closing of the access between "town and village", education did not good well because most of the teachers and school students were abducted
\end{abstract}


by a gang of DI/TII, the removal of the social strata and activities that deviate from the teachings of Islam. The method used in this study the method of historical research with through four stages, namely : heuristics, the criticism, an interpretation, and historiography. Heuristik is an activity of collecting the history associated with the topic of discussion through research library and an interview. Criticism of the form of criticism external and criticism of internal matters in order to get an authentic. Then the interpretation or the provision of the meaning of the data obtained as to be compiled into the historical facts, which was written into works of history are arranged in chronological order.

\section{Keywords : DI/TII, Bulukumba, Turbulence}

\section{A. Pendahuluan}

Berdirinya gerakan DI/TII di Sulawesi Selatan di bawah pimpinan Kahar Muzakkar khususnya di daerah Bulukumba berawal dari persilangan persepsi antara pemerintah dan para gerilyawan (KGSS) mengenai rasionalisasi ketentaraan pasca Konferensi Meja Bundar (KMB). Perbedaan pendapat ini tidak dapat terselesaikan setelah KGSS mengorganisasikan diri kedalam CTN, kemudian menjelma menjadi TKR, dan kemudian hari melebur diri dalam suatu kesatuan yang dikenal dengan Darul Islam/Tentara Islam Indonesia.

Puncak pertentangan ini terjadi pada tanggal 1 Juli 1950 di dalam sebuah rapat saat Panglima TT. VII/Wirabuana, A.E Kawilarang menolak usulan Kahar Muzakkar atas nama kaum gerilyawan yang ingin diintegrasikan ke dalam TNI dengan nama Resimen Hasanuddin. (Barbara Sillars Harvey, 1989) Untuk menjawab kekecewaan tersebut, Kahar Muzakkar beserta pasukannya melalukan pemberontakan terhadap pemerintah yang sah dengan melakukan perang gerilya, hal ini disesuaikan dengan kondisi geografis Sulawesi Selatan yang mempunyai medan yang berbukit-bukit, dan hutan-hutan yang lebat. Dalam hal ini wilayah Bulukumba mempunyai kriteria yang dimaksud dalam melakukan perang gerilya.

Daerah Kindang merupakan wilayah pertama yang diduduki oleh gerombolan diawal keberadaannya. Dalam perkembangannya, hampir keseluruhan wilayah Bulukumba dikuasai oleh gerombolan DI/TII karena gerakan mereka bersifat mobilisasi. Mayoritas penduduk Bulukumba yang menganut agama Islam memudahkan Kahar Muzakkar dalam memperoleh pengikut. GPII yang merupakan salah satu organisasi pemuda Islam yang ada di Bulukumba turut mendukung keberadaan DI/TII dengan adanya anggota pengurus GPII yang berperan dalam penyebaran pamflet DI/TII di Bulukumba. Pendudukan DI/TII di Bulukumba tidak terlepas pula dari faktor ekonomi. Hasil - hasil komoditi Bulukumba seperti kopra, kayu, hasil-hasil pertanian jangka pendek seperti padi, jagung, kacang-kacangan yang dimanfaatkan gerombolan DI/TII untuk kebutuhan hidup dan selebihnya ada yang jadikan barang dagangan selundupan.

Reaksi masyarakat adat Bulukumba yakni Kajang turut mewarnai perjalanan DI/TII di Bulukumba, adanya penolakan keras yang dilakukan oleh masyarakat Kajang Dalam (Ammatoa) dengan mengusung gerakan Dompea sebagai bentuk perlawanan terhadap gerakan DI/TII yang berusaha untuk mengubah tatanan adat dan menegakkan syariat Islam pada masyarakat Kajang Ammatoa. Wilayah Bulukumba yang tidak hanya terdiri dari bukit dan hutan yang lebat tetapi juga memiliki wilayah pantai yang cukup luas yang menjadikan gerilya DI/TII tidak hanya berlangsung di daratan tetapi juga melalukan gerilya di lautan.

Kajian tentang DI/TII telah banyak ditulis oleh berbagai pihak dengan ragam perspektif, Penelitian tentang DI/TII di 
Bulukumba sebelumnya telah ditulis oleh Abd. Karim berupa skripsi yang berjudul "Gerakan Dompea Pengaruhnya Terhadap Aktivitas DI/TII di Kecamatan Kajang Kabupaten Bulukumba Tahun 1955-1957" dan tesis karya Amirullah yang berjudul "Gerakan Darul Islam/Tentara Islam Indonesia (DI/TII) di Kajang Bulukumba Tahun 1955-1957”. Kedua tulisan tersebut secara khusus mengkaji tentang perlawanan masyarakat adat Kajang (Gerakan Dompea) terhadap gerombolan DI/TII yang berusaha untuk menghapus nilai dan norma tradisional masyarakat Kajang yang menjunjung tinggi ajaran Patuntung dan berpegang teguh pada Pasanga yang dianggap oleh DI/TII sebagai suatu hal yang bertentangan dengan islam. Dalam kajian tersebut belum utuh mengkaji keadaan Bulukumba pada masa DI/TII karena fokus kajiannya berada pada satu wilayah kecamatan sehingga tulisan ini dibuat untuk melengkapi kajian tersebut dengan memberikan gambaran objektif keadaan Bulukumba di tengah pergolakan DI/TII.

\section{B. Metode Penelitian}

Penelitian ini diarahkan untuk mengungkap kembali peristiwa unik dan berpengaruh yang terjadi di masa lampau sehingga metode penelitian yang digunakan ialah metode penelitian yang sifatnya kualitatif (Sugeng Priyadi, 2012). Dengan adanya metode sejarah, maka penelitian yang dilakukan akan lebih mudah dipahami oleh peneliti itu sendiri. Sebagaimana yang diungkapkan Kuntowijoyo terdapat lima tahapan penelitian sejarah yaitu, pemilihan topik, pengumpulan sumber, verifikasi (kritik sejarah, keabsahan sumber), interpretasi: analisis dan sintesis, dan penulisan. (Kuntowijoyo, 2005)

\section{Heuristik}

Tahap ini merupakan tahap mengumpulkan sumber-sumber sejarah yang relevan dengan topik penelitian. Kegiatan ini diarahkan pada pencarian dan pengumpulan sumber yang berkaitan dengan masalah atau objek yang dikaji, yaitu "DI/TII di Bulukumba 1952-1965". Dalam melakukan pengumpulan sumber ditempuh melalui dua cara yaitu penelitian pustaka dan penelitian lapangan.

\section{a. Penelitian Pustaka}

Pada tahap ini penulis berusaha mengumpulkan sumber-sumber pustaka yang erat kaitannya dengan judul yang dikaji. Adapun bahan-bahan pustaka yang digunakan antara lain: buku-buku, laporan penelitian, dokumen, arsip berupa Inventaris Arsip Bulukumba 1930-1960 No. Reg 80 yang berisi laporan Assisten Wedana Wedana Andi Syamsuddin mengenai masalah penangkapan dan pemeriksaan lima orang yang dicurigai sebagai gerombolan di Kajang Bulukumba, tanggal 4 Juli 1952, No. Reg 82 Laporan dari Kepala Distrik Gantarang kepada KPN Bulukumba mengenai adanya sepuluh orang gerombolan yang memakai pakaian preman dan membawa senjata api di Kampung Borongloe Dauleng Gantarang tangal 6 November 1952, No Reg 85 yang berisi Surat KPN Bulukumba kepada para Kepala Wanua se Daerah Bulukumba dan Kepala Polisi Bulukumba mengenai gerak gerik gerombolan Kahar Muzakkar, No Reg 88 Surat Kepala Distrik / Pimpinan Umum OPR Bulukumba kepada KPN Bulukumba mengenai terjadinya pertempuran antara OPR dengan gerombolan DI/TII di Bulukumba, No Reg 89 Surat KPN Bulukumba kepada Kepala Daerah Bonthain dengan lampiran namanama anggota DI/TII di Distrik Gantarang yang melapor di Ponre tahun 1959, Inventaris Arsip Propinsi Sulawesi 19501960 dengan No. Reg 323 yang berisi Dasar Pemerintahan Organisasi Militer Kahar Muzakkar 1952-1953, No. Reg 327 yang berisi Piagam Makalua, Ikrar Gerombolan DI/TII 1957, No. Reg 331 - 333 yang berisi berkas mengenai gerombolan DI/TII di daerah Sulawesi Selatan tahun 19531959, Inventaris Arsip Propinsi Sulawesi Rahasia 1946-1960 No Reg 531 yang berisi Kepala Daerah Bulukumba: Surat-surat tahun 1952-1953 tentang masalah yang berhubungan dengan aksi gerombolan 
DI/TII di Bulukumba, Inventaris Koleksi Pribadi Muhammad Saleh Lahade 19371973 No. Reg 191 yang berisi Berkas mengenai kegiatan gerombolan DI/TII Kahar Muzakkar di Sulawesi Selatan dan Tenggara. Bahan-bahan pustaka tersebut penulis peroleh dari sejumlah perpustakaan, yakni (1) Perpustakaan Jurusan Pendidikan Sejarah Fakultas Ilmu Sosial Universitas Negeri Makassar yang penulis dapatkan berupa (a) buku dengan judul Mengapa Mereka Memberontak ? Dedengkot Negara Islam karya Ruslan, dkk; (b) laporan penelitian karya Abd. Karim dengan judul Gerakan Dompea Pengaruhnya Terhadap Aktivitas DI/TII di Kecamatan Kajang Kabupaten Bulukumba Tahun 1955-1957; (2) Perpustakaan Umum Universitas Negeri Makassar, sumber yang diperoleh berupa laporan penelitian dengan judul Gerakan Darul Islam/Tentara Islam Indonesia (DI/TII) di Kajang Bulukumba (1955-1957) karya Amirullah; (3) Perpustakaan Wilayah Provinsi Sulawesi Selatan, sumber yang penulis peroleh berupa buku dengan judul Misteri Kahar Muzakkar Masih Hidup, Kisah Tertembaknya Kahar Muzakkar karya A. Wanua Tangke; (4) Perpustakaan Universitas Hasanuddin, yakni berupa laporan hasil penelitian dengan judul Sulawesi Selatan: Integrasi Gerilya ke dalam Tentara Republik karya Abd. Latif; (5) Badan Perpustakaan dan Arsip Daerah Sulawesi Selatan yang penulis peroleh berupa (a) Arsip yang terdiri dari Arsip Pribadi Muhammad Saleh Lahade 19371973, Arsip Daerah Bulukumba 19301960, Arsip Propinsi Sulawesi 1950-1960, Arsip Propinsi Sulawesi (Rahasia) 19461960; (b) Buku-buku yang penulis peroleh yakni Naskah Sejarah "Corps Hasanuddin" "Prajurit Tempur dan Pembangunan" karya Radjik Djarwadi, Sekretaris Jenderal Corhas, buku Republik Indonesia Propinsi Sulawesi dari Kementerian Penerangan (6) Perpustakaan dan Kearsipan Kabupaten Bulukumba yang penulis peroleh yakni buku karya A. Wanua Tangke dengan judul Jejak-jejak radikal Kahar Muzakkar.
Selain sumber pustaka yang penulis peroleh dari perpustakaan, dalam menyusun karya ini penulis juga menggunakan beberapa buku koleksi pribadi yakni antara lain buku yang berjudul Abdul Qahhar Mudzakkar dari Patriot Hingga Pemberontak karya Anhar Gonggong, buku yang berjudul Pemberontakan Kahar Muzakkar dari Tradisi ke DI/TII karya Barbara Sillars Harvey, dan lain-lain.

\section{b. Penelitian Lapangan}

Kegiatan yang dilakukan dalam penelitian lapangan ini adalah dengan jalan mengumpulkan sumber secara langsung melalui wawancara di lapangan terkait judul tersebut. Adapun pihak yang peneliti wawancarai yakni pihak-pihak yang memiliki kapasitas pengetahuan yang banyak terkait DI/TII di Bulukumba. Sumber lisan melalui teknik wawancara merupakan langkah yang tepat karena dengan demikian peneliti secara langsung tahu dan aktif dalam penelusuran pengumpulan data. Narasumber peneliti terbagi menjadi dua kategori: (1) informan kunci yakni informan yang memiliki kapasitas pengetahuan yang lebih banyak tentang DI/TII di Bulukumba, dan (2) informan pangkal yakni informan yang sifatnya sebagai pelengkap dari informan kunci. Adapun informan tersebut yakni Kamaluddin Jaya, Zainuddin Fatma, Darwis Rohe, Kebbong, Jalamuddin Beto, Jupri, Muh. Arbi, Jarre, Jabi, Saripuddin.

\section{Kritik}

Setelah memperoleh sumber-sumber yang memadai, tahap selanjutnya yakni kritik (penyaringan) terhadap sumber tersebut guna mendapatkan data yang otentik. Dua aspek yang dikritik ialah otensitas (keaslian sumber) dan kredibilitas (tingkat kebenaran informasi) sumber sejarah. Kritik terhadap sumber bertujuan untuk memperoleh fakta-fakta yang seobyektif mungkin, sehingga karya sejarah yang dihasilkan merupakan produk dari proses ilmiah yang dapat dipertanggungjawabkan. 


\section{Interpretasi}

Tahapan ini merupakan langkah setelah kritik sumber. Sumber-sumber sejarah yang telah didapatkan sifatnya masih bisu. Oleh karena itu, perlu ditafsirkan oleh peneliti. Interpretasi dapat dilakukan dengan cara membandingkan data yang telah diperoleh dengan data yang telah ada sebelumnya sehinga seorang peneliti mampu menyusun fakta-fakta sejarah yang dapat dibuktikan kebenarannya. Dalam hal ini tentunya peneliti harus melihat kondisi konteks lapangan dengan berbagai sudut pandang untuk menghasilkan pemahaman yang mendetail. Cara memandang sebuah peristiwa kita diharuskan tidak terbuai dengan cerita sejarah yang dipaparkan agar unsur subjektifitas bisa dihindari.

\section{Historiografi}

Pada tahap ini fakta sejarah yang telah diinterpretasikan itu selanjutnya dirangkai menjadi sebuah karya sejarah yang memenuhi kaidah-kaidah tertentu, berupa sebuah kisah sejarah yang dapat dipertanggungjawabkan oleh penulis itu sendiri.

\section{Pembahasan}

\section{Latar Belakang Keberadaan Gerakan DI/TII di Bulukumba 1952-1965}

Reorganisasi Angkatan Darat awalnya dicetuskan oleh Moh. Hatta sebagai bentuk penataan personil (pertahanan) militer dalam negeri untuk mempersatukan semua satuan bersenjata non reguler yang banyak terdapat di berbagai wilayah Indonesia ke dalam formasi Tentara Nasional Indonesia yang dikenal sebagai Brigade XVI. komandan pasukan gabungan Brigade XVI adalah Letnan Kolonel Lembong dan wakilnya Letkol J.F Warouw yang pengangkatannya menjadi polemik di kalangan pasukan Bugis-Makassar yang berasal dari Sulawesi Selatan yang mengharapkan dipimpin oleh Letkol Kahar Muzakkar. Adanya ketidakpercayaan dan ketidakpuasan dari para anggotanya menjadikan Kolonel Lembong menjabat cukup singkat, dan kemudian diangkat Letnan Kolonel J.F Warouw sebagai ketua dan Letnan Kolonel Kahar Muzakkar sebagai wakilnya. (Barbara Sillars Harvey, 1989) Tanggal 17 Oktober 1949, Kahar Mudzakkar diberi mandat oleh Kolonel Bambang Supeno untuk membentuk Komando Group Seberang (KGS) yang mempunyai tugas utama untuk mengorganisir pasukan yang berasal dari Kalimantan dan wilayah Timur Indonesia lainnya termasuk Sulawesi untuk kemudian dikirim kembali ke daerahnya untuk mempersiapkan kekuatan teritorialnya. (Barbara Sillars Harvey, 1989)

Kahar Muzakkar mengutus Saleh Syahban pada bulan Februari 1949 ke Sulawesi Selatan untuk mengadakan kontak dengan para pejuang gerilya yang pro kepada republik, dalam pertemuan tersebut Saleh Syahban mengumpulkan semua gerilyawan untuk dihimpun dalam satu wadah yang kemudian dikenal dengan nama Kesatuan Gerilya Sulawesi Selatan (KGSS). Dalam konferensi yang dilakukan oleh KGSS pada bulan Desember 1949 di Maros, ditetapkan status kelaskaran menjadi batalion yang kemudian terhimpun dalam 10 batalion. Dalam konferensi tersebut pula, para gerilyawan mengajukan usul kepada pemerintah agar mereka segera diresmikan menjadi tentara APRIS dan dibentuk dalam suatu divisi yakni divisi Hasanuddin yang personilnya diambil dari seluruh gerilyawan tanpa melalui seleksi dan mereka mengajukan Kolonel Kahar Muzakkar sebagai komandannya. (Anhar Gonggong, 1992) Keinginan dari para gerilyawan tersebut kemudian disampaikan kepada Kolonel Kawilarang sebagai Panglima TT/VII Wirabuana. Upaya negoisasi Kahar Muzakkar mewakili kaum gerilyawan tidak menuai kesepakatan dengan pemerintah karena perbedaan persepsi. Para gerilyawan menghendaki agar mereka diintegrasikan ke dalam APRIS secara keseluruhan tanpa melalui seleksi. Namun berdasarkan ketentuan pemerintah, bahwa untuk menjadi tentara republik harus memenuhi beberapa persyaratan dan diseleksi berdasarkan standar kesehatan, pendidikan, 
kemampuan membaca/menulis, dan menghendaki penerimaan anggota KGSS per batalion. Penolakan usulan Kahar Muzakkar oleh Panglima TT/VII Wirabuana merupakan cambukan keras bagi Kahar Muzakkar, yang menganggap bahwa keadaan tersebut sebagai bentuk diskriminasi terhadap gerilyawan yang berjuang di Sulawesi Selatan, setelah perang kemerdekaan usai kurang lebih 15.000 orang tidak mempunyai status yang jelas atas jasa-jasa yang mereka lakukan selama revolusi. (Kementerian Penerangan, 1953) Tuntutan dari para gerilyawan untuk dibentuk dalam suatu Divisi Hasanuddin didasarkan pada kesatuan-kesatuan di daerah Jawa dan Sumatera yang telah dibentuk. Menyikapi penolakan tersebut, Kahar Muzakkar meletakkan jabatannya dan menanggalkan tanda pangkatnya di hadapan Kolonel Kawilarang. Atas sikap Kahar Muzakkar tersebut, Panglima TT/VII Wirabuana mengeluarkan dekrit bahwa KGSS dan organisasi gerilya diluar APRIS dianggap telah bubar dan segala upaya untuk menghidupkan organisasi tersebut dilarang. Akibat dari penolakan tersebut membuat Kahar Muzakkar bersama pasukannya membangkang dan melarikan diri masuk ke hutan belantara untuk mengadakan perang saudara.

Menyikapi permasalahan "status gerilya" pemerintah kemudian melakukan berbagai cara untuk mengajak gerilyawan untuk kembali ke pangkuan Negara Kesatuan Republik Indonesia dengan membentuk Corps Tjadangan Nasional (CTN) persiapan TNI/Brigade Hasanuddin pada akhir tahun 1950. Langkah pertama yang ditempuh yaitu melakukan perekrutan yang menurut Harvey direncanakan sekitar 30.000 bekas gerilyawan di seluruh negara akan dimasukkan kedalam CTN. Di Sulawesi Selatan, CTN merupakan suatu organisasi peralihan, kaum gerilyawan akan diterima ke dalam satuan-satuan yang telah ada tanpa melalui proses penyaringan. Sebagai anggota CTN, mereka yang ingin didemobilisasikan akan dibantu mencari pekerjaan atau masuk sekolah. Sebagai langkah lanjutan dalam penyelesaian masalah KGSS, tanggal 24 Maret 1951 para gerilyawan kemudian dilantik menjadi Corps Tjadangan Nasional (CTN) dan terbentuk lima formatur batalion beserta rayon penempatannya. Tanggal 14 Agustus 1951, 3 hari sebelum pelantikan anggota CTN Kahar Muzakkar berhasil mempengaruhi sejumlah oang untuk meninggalkan rayon CTN dan mengadakan penyerangan terhadap truk-truk yang akan menjemput para anggota CTN yang berada di rayon-rayon dan merampas perlengkapan senjata. Di hari pelantikan tanggal 17 Agustus 1951, Kahar Muzakkar beserta anggota-anggotanya tidak memenuhi janjinya untuk hadir yang dianggap sebagai suatu penghinaan atas kehormatan nasional. Perdana Menteri Sukiman memberikan amnesti 5x24 jam bagi gerilyawan untuk segera melaporkan diri namun instruksi tersebut tidak diindahkan sehingga terjadi kontak senjata antara kedua belah pihak. (Barbara Sillars Harvey, 1989)

Dalam perkembangan selanjutnya, CTN dijelmakan menjadi Tentara Kemerdekaan Rakyat (TKR) pada tanggal 24 Maret 1952. Bentuk pemerintahannya adalah militer dengan sistem Distrik Militer atau Wherkraise yang diberlakukan pada tanggal 5 Juli 1952. Dalam penetapan tersebut dijelaskan bahwa untuk memudahkan jalannya administrasi dan teknik organisasi TKR, maka daerah Sulawesi (sebagai daerah basis TKR) dibagi menjadi dua daerah militer yakni, territorium de facto militer dan territorium luar de facto militer. Territorium de facto militer meliputi daerah-daerah yang telah dapat distabilisasi dan dibentuk pemerintahan militer. Daerah tersebut diatur dengan sistem wherkraise. Territorium luar de facto militer terdiri dari daerah-daerah yang belum dapat distabilisasi dan dibentuk pemerintahan militer. Daerah itu diatur dengan jalan mengadakan Komando Pos (Commandoposten) yang berkedudukan sebagai badan perwakilan dari Komando 
Pasukan Hasanuddin. (Arsip Pribadi Muhammad Saleh Lahade No. Reg 191, 1937-1973)

Pusat TKR di Bulukumba berada di Daerah Kindang, tepatnya di kampung Senggang dengan markasnya sebuah rumah kosong di sebelah sungai Bialo. Mereka menamakan dirinya TKR SS BCO : $\mathrm{CP} / 3$, pemimpin dari TKR tersebut adalah Palar Jusuf dan terdiri dari satu kompi, yang anggotanya semua berasal dari Palopo. Persenjataannya terdiri atas 1 senjata bren, 1 senjata longser, 1 senjata tomson dan yang lainnya memiliki pistol. Diketahui bahwa TKR ini memperoleh dukungan dari Karaeng Kindang dengan adanya bantuan dari Karaeng Kindang dengan mempekerjakan seorang guru bantu di kantornya untuk mengurus segala kepentingan dari TKR termasuk pula administrasinya. (Inventaris Arsip Khasanah Bulukumba No Reg. 82, 19301960)

Kahar Muzakkar dikemudian hari menyatakan gerakannya sebagai bagian dari DI/TII dan NII pimpinan Kartosuwiryo pada 7 Agustus 1953. Kahar Mudzakkar menyatakan daerah Sulawesi dan daerah sekitarnya (meliputi Indonesia bagian Timur termasuk Irian, menjadi bagian dari NII, di mana Kahar Mudzakkar sendiri menjabat sebagai Panglima Teritorium IV Tentara Islam Indonesia (Panglima TT. IV. T.I.I.). (Arsip Pribadi Muhammad Saleh Lahade No. Reg 191, 1937-1973). Dengan adanya peleburan tersebut, maka TKR yang ada di Bulukumba kemudian dijelmakan menjadi DI/TII, yang semula susunan pemerintahan militer dan organisasi TKR berdasarkan pertahanan rakyat total diganti menjadi rencana mobilisasi umum. (Inventaris Arsip Propinsi Sulawesi No. Reg 331, 1950-1960)

\section{a. Posisi Bulukumba dalam Struktur} DI/TII

Sebagai tindak lanjut dari pernyataan penggabungan dengan DI/TII dan NII pimpinan Kartosuwiyo, melalui surat yang dikeluarkan oleh Kahar Muzakkar No. 5/IV/HS/A/54 tanggal 15 Januari 1954 atau
10 Jumadil Awal 1373, Kahar Muzakkar memutuskan membentuk pemerintah sipil Negara Indonesia Islam, dalam garis besarnya Provinsi Sulawesi dibagi atas 4 keresidenan yakni (1) Keresidenan Sulawesi Timur, meliputi daerah Bone, Luwu, Buton dengan acting residennya Syamsul Bahri; (2) Keresidenan Sulawesi Utara, meliputi daerah Minahasa, Poso, Donggala dengan acting residennya Andi Tenriadjeng; (3) Keresidenan Sulawesi Selatan, meliputi daerah Makassar, Bantaeng, dengan acting residennya Bahar Mattaliu; (4) Keresidenan Sulawesi Barat, meliputi daerah Pare-Pare, Majene, Toraja, dengan acting residennya Sanusi Daris. Keempat keresidenan tersebut dibawahi oleh Gubernur B.S Baranti. Dengan perincian commandoposten dengan daerah aksinya, yakni (1) C.P I, daerah aksinya Sulawesi Tengah (Poso); (2) C.P II, daerah aksinya Mandar; (3) C.P III, daerah aksinya Bonthain; (4) C.P IV, daerah aksinya Sulawesi Tenggara. Wilayah Bulukumba merupakan bagian dari Kabupaten Bonthain (Bantaeng). (Arsip Pribadi Muhammad Saleh Lahade No. Reg 191, 1937-1973)

Bulukumba sebagai aanvalbasis yang didefinisikan sebagai daerah pengaruh musuh dijadikan sebagai pangkalan pertempuran daerah komando DI/TII dengan satuan C.P III (Commandoposten III) memiliki tugas untuk mempengaruhi masyarakat guna menstabilisasi pemerintah bayangan, dan aktif dalam usaha-usahanya untuk menginfiltrasi pihak Angkatan Perang dan Kepolisian. Jumlah pasukan CP III di Bulukumba sebanyak \pm 60 orang dengan persenjataan sebanyak 30 pucuk senjata beragam jenis, dan 1 bren. Pemimpin CP III di Bulukumba yakni Mahmud Basri. (Arsip Pribadi Muhammad Saleh Lahade No. Reg 191, 1937-1973)

Dalam perkembangan selanjutnya, Kahar Muzakkar membentuk dan melantik empat divisi di Indonesia Bagian Timur. Untuk wilayah Sulawesi Selatan dibentuk Divisi II 40.000 yang dipimpin oleh Bahar Mattaliu. Panglima Divisi II 40.000 Bahar 
Mattaliu membawahi empat resimen tentara dan 16 batalion/Komando Daerah Bawahan (KDB). Bulukumba berada di bawah Resimen IV Ali A.T batalionnya terdiri atas Batalion 13 DI/TII dengan Komandan M. Marzuki Rijal, Batalion 14 DI/TII dengan Komandan Amir Rauf, Batalion 15 DI/TII dengan Komandan Jusuf Palar, Batalion 16 DI/TII dengan Komandan Abd. Azis B.R.

Daerah Kindang merupakan wilayah pertama yang diduduki oleh gerombolan diawal keberadaannya di Bulukumba. Hal ini didukung dengan keadaan geografisnya yang berbukit-bukit, dan hutannya yang lebat menjadi tempat yang cocok untuk aksi gerilya yang mereka lakukan. Daerah yang luas dengan jalan-jalan yang terbatas memberikan suatu medan gerilya yang sangat menguntungkan. Dalam perkembangannya, hampir keseluruhan wilayah Bulukumba dikuasai oleh gerombolan DI/TII karena gerakan mereka bersifat mobilisasi. Taktik gerombolan untuk mendapat dukungan masyarakat Bulukumba yaitu menggunakan pendekatan kekeluargaan dan emosi keagamaan di bawah panji-panji Islam. Mayoritas penduduk Bulukumba menganut agama Islam sehingga memudahkan Kahar Muzakkar dalam memperoleh pengikut.

\section{b. DI/TII sebagai Pilihan : Penggabungan diri Masyarakat Bulukumba}

Berbagai faktor yang melatarbelakangi rakyat Bulukumba untuk menggabungkan diri dengan pasukan DI/TII yaitu faktor penarik dan faktor pendorong. Faktor penarik merupakan faktor yang berasal dari DI/TII sehingga masyarakat Bulukumba bergabung dengan DI/TII sedangkan faktor pendorong merupakan faktor yang berasal dari diri ataupun lingkungan masayarakat itu sendiri. Faktor penarik dapat dilihat dari kehidupan orang-orang telah lebih dulu bergabung dengan DI/TII yang kehidupannya lebih terjamin. Seperti dalam hal makanan, para anggota DI/TII memperoleh makanan dari masyarakat. (Beso, 2018) Islam juga merupakan salah satu faktor penarik dilihat dari adanya guru- guru agama yang kemudian bergabung dengan DI/TII karena atas dasar memperjuangkan Islam. (Jaya, 2018)

$$
\text { Adapun faktor pendorong }
$$

bergabungnya masyarakat Bulukumba dengan gerakan DI/TII yaitu karena banyak pemuda yang tidak memiliki pekerjaan tetap sehingga memilih untuk bergabung, selain hal tersebut ada yang bergabung karena ingin memperoleh kekuasaan, ingin ditakuti oleh masyarakat. Banyak pula yang bergabung merupakan orang-orang yang suka berjudi dan minuman keras, akan tetapi DI/TII tidak menyukai perbuatan tersebut, sehingga mereka "mengamankan diri" agar tidak dibunuh. (Rohe, 2018)

Penculikan dan pemaksaan juga menjadi salah satu faktor, yaitu dengan diculiknya guru-guru yang kemudian mereka dijadikan sebagai staf pengajar di sekolah bentukan DI/TII kemudian dijadikan pula sebagai anggota DI/TII, yang tak jarang mendapatkan posisi yang strategis dalam struktur militer ataupun pemerintahan DI/TII. Seperti Nyompa yang awalnya dijadikan sebagai staf pengajar kemudian diangkat menjadi perwira operasi Resimen IV Divisi 40.000. selain para guru, murid-murid juga turut diculik oleh gerombolan, mereka yang diculik kemudian disekolahkan di sekolah bentukan DI/TII.

\section{Aktivitas Gerakan DI/TII di Bulukumba}

Dalam memperkuat kedudukannya, gerakan DI/TII membentuk pemerintahan sipil di tiap- tiap distrik, mereka membentuk Kepala Pemerintahan Militer Distrik (KPMD), setiap KPMD membawahi 3 distrik. Pemilihan KPMD yang pertama dilakukan di SR Lembangtumbu' yang dihadiri oleh ratusan orang yang terdiri dari masyarakat hingga kepala desa dan kepala distrik. Selanjutnya juga dibentuk Komando Distrik Territorial (KDT) atau kepala distrik, mereka juga memperkuat organisasinya dengan mengangkat Iman Desa (ID) yang berperan sebagai kepala desa, Rukun Kampung (RK) 
yang berperan sebagai kepala kampung, Guru Kampung (GK) yang merupakan guru - guru di kampung tersebut. Setiap KDT didampingi oleh satu kompi TII, jadi Darul Islam (DI) dengan Tentara Islam Indonesia (TII) selalu berjalan beriringan. Dapat dikatakan bahwa, KDT adalah organisasi pemerintahan sipil yang mempunyai tugas menjalankan pemerintahan Islam sedangkan TII merupakan organisasi militer yang bertugas menjaga eksistensi wilayah yang dikuasai DI/TII dari konfrontasi militer TNI. (Jupri, 2018) Selama keberadaannya di Bulukumba berikut aktivitas-aktivitas gerombolan DI/TII:

\section{a. Penculikan dan Perampasan Harta Benda}

Berdasarkan laporan dari Kepala Pemerintah Negeri Bulukumba, pada tanggal 17 Desember 1953 jam 18.30 di kampung Maccope Bontosunggu Gantarang, dua orang guru agama dari Nahdatul Ulama bernama Abdul Rahman dan Ecang diculik oleh gerombolan di rumahnya masing-masing. Sebelum keduanya diculik, gerombolan terlebih dahulu mengadakan letusan senjata beberapa kali sehingga penduduk panik dan bersembunyi. Keduanya kemudian dibawa oleh gerombolan menuju kampung Palioi Gantarang. Berdasarkan laporan tersebut, dapat disimpulkan bahwa penculikan terhadap guru agama yang bernama Abdul Rahman dan Etjang tersebut oleh gerombolan akan dijadikan sebagai tenaga guru bagi sekolah agama milik DI/TII. (Inventaris Arsip Propinsi Sulawesi No. Reg 331, 1950-1960)

Selain melakukan penculikan terhadap guru, murid, dan rakyat biasa. Gerombolan DI/TII juga melakukan aksi perampasan harta benda atau perampokan, aksi ini dilakukan di jembatan Bijawang yang merupakan lokasi yang strategis bagi gerombolan untuk melakukan penghadangan. tanggal 27 Februari 1959 sore, dua buah mobil truk milik haji Ambo yang masing-masing memiliki plat nomor DD 5224 dan DD 3734 ditahan oleh gerombolan DI/TII di antara KM 161/162 kampung Bacari jurusan Tanete. Dua buah truk tersebut berangkat dari Tanete menuju Bulukumba yang memuat barang dagangan beserta penumpang yang berjumlah 80 orang. Truk tersebut kemudian di bawa ke kampung Bontonyeleng yang kurang lebih $5 \mathrm{~km}$ dari jalan raya. Setibanya di kampung Likukorong Bontonyeleng, kedua truk tersebut diperintahkan untuk berhenti dan semua penumpang diperintahkan untuk turun guna diperiksa satu persatu dan dalam pemeriksaan ini semua surat pas dan uang para penumpang diambil oleh gerombolan DI/TII. Setelah itu, mereka disuruh untuk sholat maghrib di mesjid yang berada di kampung tersebut. Menurut salah satu korban yang berhasil meloloskan diri yakni Palanai, setelah menunaikan sholat maghrib, para penumpang diperintahkan kembali naik ke mobil dan dibawa ke jurusan barat arah kampung Kalukue. Gerombolan tersebut memiliki 3 senjata brengun, 3 mortier 2 inch. (Inventaris Arsip Propinsi Sulawesi No. Reg 331, 1950-1960). Gerombolan juga melakukan pencurian terhadap kuda-kuda masyarakat, berdasarkan laporan Kepala Pemerintahan Bulukumba, sebanyak 7 ekor kuda milik Nuhung dicuri oleh gerombolan dengan total kerugian sebesar Rp. 9.550.

Konsentrasi wilayah operasi gerombolan DI/TII Bulukumba tidak hanya di daratan melainkan operasi juga mencakup wilayah perairan Bulukumba dengan melancarkan strategi perjuangan gerilya laut. Dengan menyerang sasaran saat lemah, taktik gerilya laut ditujukan kepada penduduk pesisir pantai, dan para pelayar. Konsentrasi gerilya laut ini berada di perairan Gantarang, wilayah timur Bulukumba yakni, Hero, Lange-Lange, Ara, Bira dengan penempatan satu batalion yakni batalion 16 Resimen IV Divisi 40.000. Laporan aktivitas penculikan dan perampokan di laut yaitu laporan Kepala Pemerintah Negeri Bulukumba, perahu "Sinar Sejati" milik Manggalea dihadang oleh gerombolan di perairan distrik Tiro 
ketika Manggalea dalam perjalanan dari Kabaena ke Bulukumba dengan memuat ikan kering, kerugian ditaksir sebanyak Rp. 18.000. Manggalea dan 4 orang anak buahnya dibawa serta oleh gerombolan yakni, Djunaeda berumur 47 tahun dari kampung Tanah Kongkong, Mading berumur 45 tahun asal dari kampung Nipa, Nasire yang berumur 20 tahun dan Samesun yang berumur 18 tahun berasal dari Kasimpureng. Laporan Kepala Distrik Bulukumba Toa bahwa pada tanggal 25 Maret 1959 jam 15.30, seorang lelaki yang bernama Tahang yang merupakan juragan perahu, ia berangkat dari Bantaeng ingin kembali ke Ujung Loe, dan di tengah lautan sekitar pantai Kalamassang Gantarang perahu Tahang tersebut dihadang oleh gerombolan yang membawa senjata api sebanyak 9 pucuk, perahunya diperintahkan mendarat di pantai Kalamassang dan barang-barang milik Tahan dan milik teman-temannya diambil oleh gerombolan tersebut, di antaranya yaitu barang-barang milik Samagga yang berasal dari kampung Salabba Ujung Loe yakni uang kontan sebanyak Rp. 2150, minyak tanah 1 drum Rp. 30, sarung benang satu lembar Rp. 40, songkok hitam beledru Rp. 20. Uang milik Tahang sebesar Rp. 1.015, dan barang-barang milik Sumang yaitu uang kontan Rp. 6.850, bawang merah 100 liter Rp. 600, kacang hijau Rp. 250, tikar 40 lembar Rp, 200. Total kerugian sebesar Rp. 11.360. (Inventaris Arsip Propinsi Sulawesi No. Reg 331, 1950-1960)

Menurut laporan Kepala Distrik Gantarang, gerombolan DI/II melakukan pencegatan terhadap perahu lambo milik Nasir di perairan Tanah Beru, seluruh muatan kapalnya diambil, ia beserta sawinya yang bernama Bulla diculik kemudian direkrut menjadi anggota DI/TII. (Inventaris Arsip Khasanah Bulukumba No Reg 89b, 1930-1960). Untuk kepentingan berlangsungnya gerakan, pelabuhan di Bulukumba khususnya pelabuhan Tiro digunakan untuk penyelundupan hasil - hasil bumi seperti kopra dan kayu sebagai barang dagangan yang diselundupkan sampai ke Singapura dan Tawau. Hasil-hasil penjualan komoditi tersebut kemudian dipergunakan untuk membeli senjata, pakaian anggota, dan lain-lain. Pedagang yang menjadi perantara dalam menjalankan penyelundupan tersebut ialah Hammade Lopo. (Inventaris Arsip Propinsi Sulawesi No. Reg 106, 1950-1960)

\section{b. Aksi Kekerasan}

Berdasarkan laporan dari Kepala Pemerintah Negeri Bulukumba, Muh Arzad bahwa pada tanggal 15 Agustus 1953, seorang lelaki bernama Andi Patiroi yang merupakan Menteri Pengairan landshap Gantarang yang juga seorang anggota penyelidik staf 1/bn 722 mati terbunuh oleh gerombolan di kampung Barabba kurang lebih $3 \mathrm{~km}$ dari Bulukumba Kota. Selang tiga hari, tanggal 18 Agustus 1953 terjadi pembunuhan terhadap lelaki yang bernama Djalil penduduk kampung Malewong Gantarang, ia dibunuh di rumahnya yang kurang lebih 19 km dari Bulukumba Kota. 5 hari kemudian, Lawangeng di kampung Dampang Gantarang mati terbunuh oleh gerombolan di rumahnya kurang lebih 6 $\mathrm{km}$ dari Bulukumba Kota. Pada tanggal 5 Oktober 1959 jam 17.00 gerombolan sejumlah kurang lebih 20 orang, 4 orang di antaranya membawa senjata memasuki kampung Labojo (Kajang) dan menculik seorang lelaki bernama Patakka dan kemudian dibunuh, mayat Patakka ditemukan di kampung Kajangkeke dengan 17 luka di seluruh tubuhnya. (Inventaris Arsip Propinsi Sulawesi No. Reg 331, 19501960)

Berdasarkan laporan Kepala Distrik Ujungloe, pada hari minggu tanggal 18 Oktober 1959 jam 18.00 telah terjadi pembunuhan terhadap seorang laki-laki bernama Pakindang yang berumur 40 tahun tinggal di kampung Seppang Ujungloe. Pakindang dibunuh oleh gerombolan di kampung Bonto Marita Seppang kira-kira 300 meter dari rumahnya. Pakindang terbunuh saat ia pergi menambatkan kudanya di tempat 
tersebut, ketika ditemukan terdapat 2 luka di wajahnya, 1 luka di dada dan lehernya. Selain itu, seekor kuda jantan bulu balibi dibawa pergi oleh gerombolan. (Inventaris Arsip Khasanah Bulukumba , 1930-1960)

\section{c. Pembakaran dan Aksi Sabotase}

Sejak diumumkan Perang Semesta oleh Kartosuwiryo yaitu pemisahan secara tegas dan nyata antara wilayah yang dikuasai TNI dengan DI/TII, maka pada akhir tahun 1955 Kahar Muzakkar mengadakan Pertemuan Urgensi Pejuang Islam Revolusioner (PUPIR I) di Makalua, dari hasil pertemuan tersebut telah diputuskan yaitu menjalankan instruksi Perang Semesta yang dikeluarkan oleh Kartosuwiryo (Presiden NII). Batas garis pemisah antara daerah TNI dengan DI/TII adalah lima kilometer dari kota - kota dan jalan raya. Dalam rangkaian penetapan daerah de facto, rakyat yang berada di daerah perbatasan, yakni tiga kilometer dari kota harus memilih yaitu masuk ke daerah de facto DI/TII atau masuk kota dan menjadi musuh. ( Bahar Mattaliu, 1994) Berdasarkan penetapan daerah de facto tersebut, maka daerah - daerah yang telah ditentukan menjadi sasaran pensterilan DI/TII atau dikenal dengan "taktik bumi hangus" sedangkan pihak TNI dikenal istilah "diungsikan". Pada tahun 1956 dilancarkan aksi bumi hangus oleh gerombolan DI/TII terhadap distrik Kajang, sebanyak 194 rumah, dan 7 SR dibumihanguskan oleh DI/TII. (Inventaris Arsip Propinsi Sulawesi No. Reg 331, 19501960) Masyarakat Kajang dalam pandangan DI/TII merupakan orang-orang kafir yang harus diberantas, masyarakat Kajang yang berpegang teguh terhadap ajaran Patuntung, hal tersebut tidak sesuai dengan ajaran Islam. Aksi dari gerombolan tersebut mendapat perlawanan dari masyarakat Kajang yang mengusung suatu gerakan yang bernama Gerakan Dompea. Gerakan tersebut berhasil memukul mundur DI/TII dari tanah Kajang akan tetapi pada tahun 1957 DI/TII kembali menguasai Kajang dan membunuh orang-orang yang dianggap kafir. (Jupri, 2018)
Pembakaran juga dilakukan terhadap fasilititas pemerintahan seperti kantor wanua Tiro/Batang/Bontotanga, Ara, dan Tanahberu dibongkar serta alat-alat kantor dan arsip-arsip dibakar. Total kerugian keseluruhan sebesar Rp. 95.000. Selain itu, pembakaran Sekolah Rakyat III tahun beserta alat-alat sekolah di Tamangisi (Gantarang), kerugian Rp. 5.000. Aksi pembakaran yang dilakukan oleh gerombolan juga terdapat pada gedung balai pengobatan dan balai pengadilan, dengan kerugian Rp. 100.000. Pembakaran terhadap gedung yang dipakai sebagai Sekolah Rakyat IV tahun yang merupakan bantuan lokal dari masyarakat Kajang, dengan kerugian ditaksir Rp. 47.500. (Inventaris Arsip Propinsi Sulawesi No. Reg 106, 1950-1960)

Aksi sabotase yang dilakukan oleh gerombolan DI/TII yaitu memutus kawatkawat telepon, perusakan jembatan, penggalian jalan-jalan, penebangan pohonpohon. Berdasarkan laporan Kepala Pemerintah Negeri Bulukumba bahwa hubungan lalu lintas Bulukumba - Tanete mulai pada tanggal 8 Mei 1955 terputus akibat adanya penebangan pohon-pohon kayu di jalanan Balangpesoang - Bulo-bulo dan Buttakeke, serta adanya pengrusakan jembatan Jamulolo, Bulo-bulo, Palampang dan Katangka. Selain itu, gerombolan juga melakukan penebangan pohon, penggalian jalan-jalan, dan pemutusan kawat telepon di sepanjang jalanan jurusan Bantaeng Tanete - Ujung Loe - Kajang Kantisang dan Sawere. Aksi sabotase tersebut sebagai upaya untuk menghalau mobilitas dari TNI yang melakukan patroli. Aksi sabotase tersebut dilakukan berulang kali oleh gerombolan, jembatan dibongkar dua hingga tiga kali kemudian diperbaiki lagi oleh masyarakat. Perbaikan jembatan dilakukan siang hari oleh TNI bersama dengan masyarakat, lalu malam hari dirusak lagi oleh para gerombolan beserta masyarakat. Konflik antara pemerintah/TNI dan DI/TII menjadikan masyarakat sebagai "korban", masyarakat yang hidup di antara dua kekuatan yang 
berseteru hanya ada dua pilihan yaitu hidup atau mati.

\section{d. Reaksi Kaum Adat Kajang Bulukumba terhadap Gerakan DI/TII}

Sejak tahun 1953 gerakan DI/TII giat melakukan penerangan-penerangan terhadap masyarakat dan membangun kekuatan dengan perang gerilya untuk menyusun strategi memperluas wilayah kekuasaan yang bertujuan untuk menegakkan dan menyuarakan ide-ide negara Islam sebagai visi perjuangan mereka. Sehingga 13 distrik yang ada di Bulukumba berada dalam kekuasaan DI/TII tak terkecuali wilayah Kajang. Segera setelah berhasil membangun pemerintahan sipil dan pemerintahan militer, gerombolan DI/TII di Kajang di bawah pimpinan Abdul Hamid aktif dalam melakukan kegiatannya seperti pemungutan pajak yang dikatakan sebagai infaq oleh gerakan DI/TII, penghapusan strata ataupun golongan sosial seperti gelargelar tradisional dalam masyarakat Kajang, hal umum yang dilakukan pula pada wilayah lainnya di Bulukumba. Beda halnya dengan distrik yang lain, reaksi yang keras muncul dari masyarakat Kajang khususnya masyarakat kaum adat Kajang Ammatoa. Reaksi ini muncul dari keresahan masyarakat atas tindakan dari gerombolan DI/TII, terutama dalam hal pemurnian syariat Islam di Kajang yang serta merta ingin menghapus adat istiadat dan kepercayaan yang dianut oleh masyarakat yang berpegang teguh pada ajaran Patuntung dan Pasanga Ri Kajang yang telah menyatu dalam kehidupan mereka.

Kaum adat Kajang mengusung gerakan perlawanan terhadap DI/TII yang terhimpun dalam suatu gerakan yang bernama Gerakan Dompea yang dipimpin oleh tokoh-tokoh adat. Gerakan tersebut lahir sebagai terobosan terhadap kehidupan sosial kemasyarakatan yang tengah mengalami stagnasi dan tekanan politik yang hebat di bawah kendali gerombolan DI/TII. Perlawanan hebat ini terjadi pada tahun 1956 dengan pecahnya perang di daerah sekitar Ammatoa, gerakan Dompea yang menggunakan pakaian serba hitam, dan ikat kepala yang disebut "passapu' le'leng" dengan senjata berupa badik, dan bambu runcing. Perlawanan intensif orang-orang Dompea terhadap gerombolan dengan mengeksekusi dengan cara potong leher dalam posisi berdiri menyebabkan gerombolan DI/TII dapat disingkirkan dari tanah Kajang. Tetapi keberhasilan tersebut tidak bertahan lama karena setahun setelahnya yakni tahun 1957, gerakan DI/TII berhasil mengusung kekuatan dengan membumihanguskan daerah Kajang, orang-orang Dompea dibunuh, rumah-rumah warga di luar kawasan adat turut menjadi korban pembumihangusan DI/TII. Gerak maju yang dilakukan oleh DI/TII tersebut dengan gencar melakukan penyisiran di wilayah Timur Bulukumba, bahkan TNI yang berada di Kalimporo Kajang tidak kuasa membendung perlawanan dari gerakan DI/TII. (Jaya, 2018)

\section{Dampak Pergerakan DI/TII terhadap Kehidupan Masyarakat Bulukumba}

\section{A. Bidang Politik}

Dalam bidang politik, Bulukumba sebagai tempat berlangsungnya konflik antara DI/TII dan TNI mengakibatkan penderitaan bagi masyarakat Bulukumba. Meskipun masyarakat bukanlah pelaku konflik, tetapi masyarakatlah yang merasakan dampak dari konflik tersebut. Adanya garis pemisah yang tegas antara daerah kekuasaan TNI dan DI/TII merupakan suatu hal yang dilematis bagi masyarakat. Rakyat yang berada di daerah yang berbatasan dengan kota-kota, yakni tiga kilometer dari kota harus memilih masuk hutan ke de facto DI/TII atau masuk kota yang dalam wilayah kekuasaan TNI. Untuk DI/TII dikenal dengan "taktik bumi hangus" sedangkan untuk TNI dikenal dengan istilah "diungsikan" ke wilayah yang dikuasai oleh TNI. Akibat dari aksi bumi hangus tersebut, maka terjadi pengungsian besar-besaran di 
daerah Bulukumba. Hal yang perlu dipahami bahwa hutan tempat masyarakat Bulukumba menyingkir tersebut bukanlah hutan rimba yang belum terjamah oleh manusia, namun hutan yang dimaksud yakni daerah yang tidak diduduki oleh TNI termasuk perkampungan rakyat yang letaknya terpencil atau kampung-kampung yang letaknya jauh dari jalan raya sehingga tidak dilalui oleh TNI ketika beroperasi.

\section{B. Sosial Ekonomi}

Kekacauan yang terjadi di Bulukumba akibat adanya gerakan DI/TII berdampak pada sendi-sendi perekonomian masyakarat. Terputusnya akses antara desa dan kota memunculkan dampak yang luar biasa dalam tatanan perekonomian masyarakat. terputusnya hubungan antara desa dan kota mengakibatkan lumpuhnya perekonomian masyarakat. Masyarakat di kota yang tidak memiliki produksi beras mengalami krisis pangan karena makanan pokok masyarakat sulit untuk didapatkan. Bahan makanan sebagai pengganti beras yakni jagung dan umbi-umbian atau percampuran beras dengan jagung (beras jagung). Orang-orang yang tinggal di desa yang merupakan daerah kekuasaan DI/TII, mereka tidak berani masuk ke kota karena takut ditangkap oleh TNI karena dianggap sebagai orang DI/TII atau mata-mata dari DI/TII. Terputusnya hubungan antara desa dan kota menjadikan pasar-pasar di kota sepi, karena tidak adanya barang-barang dari desa yang disalurkan ke kota sehingga melumpuhkan roda perekonomian. (Fatma, 2018) Di lain pihak, yakni masyarakat desa juga sama merasakan dampak terhadap tertutupnya akses kota dan desa, mereka kesulitan mendapatkan minyak tanah, sabun, gula pasir, dan lainlain yang hanya bisa didapat di kota. Hasilhasil pertanian mereka juga tidak bisa dijual ke kota.

DI/TII aktif melakukan pemungutan zakat terhadap masyarakat. Zakat diambil sebanyak $10 \%$ daris setiap hasil bumi dalam sekali panen. Tanaman jagung diambil $10 \%$ setiap panen, begitupun dengan padi apabila terdapat 100 ikat, dikeluarkan 10 ikat untuk zakat. (Habi, 2018) Kondisi perekonomian juga terhambat dengan adanya pengungsian ataupun "aksi menyingkir" yang dilakukan oleh masyarakat Bulukumba ke dalam wilayahwilayah penguasaan TNI atau turut menjadi anggota DI/TII sehingga lahan-lahan pertanian mereka tinggalkan.

Dalam bidang sosial budaya, gerakan DI/TII melakukan penghapusan strata sosial dalam masyarakat, Dalam ajaran islam tidak dikenal adanya kelas-kelas sosial sehingga gerombolan ingin menerapkan kebersamaan dalam masyarakat Bulukumba, segala bentuk panggilan andi, puang, karaeng ditentang keras dan dihapuskan oleh gerombolan DI/TII. Panggilan yang boleh dipergunakan pada saat itu hanyalah Bung. Selain hal tersebut, DI/TII juga mengatur tentang uang mahar pernikahan. DI/TII mengatur mahar pernikahan atau uang panai' sebanyak Rp. 250. Hal itu ditetapkan supaya mencegah terjadinya kejahatan seksual dalam kalangan masyarakat Bulukumba karena uang panai' yang mahal. (Jarre, 2018)

\section{Pendidikan dan Keagamaan}

Tertutupnya akses antara desa dan kota juga sangat mempengaruhi kondisi pendidikan di Bulukumba, penculikan guru-guru dan murid-murid menjadikan pendidikan tidak berjalan dengan baik, para pelajar yang sebelumnya bersekolah di kota, ketika kembali ke kampung halamannya maka mereka tidak diperbolehkan lagi kembali masuk kota untuk bersekolah, jika ada yang ingin terus melanjutkan pendidikannya maka harta benda berupa ternak ataupun yang lainnya yang mereka miliki akan diambil oleh gerombolan. (Rohe, 2018)

Dalam aspek keagamaan dengan "syariat islam" yang dibawa oleh gerakan DI/TII memberikan dampak yang signifikan terhadap masyarakat Bulukumba, Adanya gerakan DI/TII di Bulukumba, ormas islam Muhammadiyah merasa terbantu dengan adanya gerakan tersebut karena mereka memiliki misi yang sama yakni menentang segala praktek kesyirikan, 
bid'ah dan jenis-jenis kufarat. Dalam hal pelaksanaan qunut pada sholat subuh, masyarakat Tiro masih sering melakukan hal tersebut. Pembacaan talqin di kuburan juga mulai berkurang, selain hal tersebut pemukuluan bedug sebanyak 4 kali saat memasuki waktu shalat dhuhur turut pula dihapuskan oleh DI/TII. (Fatma, 2018)

Meskipun sebagain besar orang-orang pada saat itu melaksanakan shalat hanya karena takut, tetapi lambat laun aktivitas shalat di mesjid rutin dilakukan oleh masyarakat dan dalam keadaan ikhlas. Segala bentuk praktek yang mengandung unsur syirik, bid'ah dan kufarat diberantas oleh DI/TII, seperti tempat-tempat yang dianggap keramat yang diberikan sesajian, rumah-rumah yang di dalamnya terdapat anrong batara, anrong pare yang biasanya di simpan di atap rumah atau di tiang rumah, pelaksanan ma'baca-baca baik itu ma'bacabaca setelah menempati rumah baru ataupun yang lainnya, kemudian praktek semacam itu dihilangkan oleh DI/TII. Gerombolan DI/TII juga menetapkan akkammisi yaitu sholat untuk perempuan yang dilakukan pada hari Kamis, karena perempuan tidak sholat jum'at.

\section{DAFTAR PUSTAKA}

Mattaliu, Bahar, 1994. Pemberontakan Meniti Jalur Kanan, Jakarta: Gramedia Widiasarana Indonesia.

Gonggong, Anhar, 1992. Abdul Qahhar Mudzakkar dari Patriot Hingga Pemberontak. Jakarta: Gramedia Widiasarana.

Arsip Pribadi Muhammad Saleh Lahade, 1937-1973. No. Reg 191, Makassar: Badan Perpustakaan dan Kearsipan Sulawesi Selatan.

Harvey, Barbara Sillars, 1989. Pemberontakan Kahar Muzakkar dari Tradisi ke DI/TII. Jakarta: Grafiti Pers.

Beso, J., 2018. [Wawancara] (20 Maret 2018).
Pelaksanaan akkammisi sama seperti sholat dhuhur biasa yakni 4 rakaat. (Rohe, 2018)

\section{Kesimpulan}

Keberadaan gerakan DI/TII di Bulukumba dipengaruhi oleh beberapa faktor. yakni keadaan geografis yang cocok untuk perang gerilya, faktor agama Islam, adanya fanatisme agama, ikatan kekeluargaan, faktor perekonomian yang dijadikan oleh DI/TII sebagai sumber pendapatan dalam mendukung gerakannya. Para guru dan pelajar juga turut aktif dalam kegiatan militer dan pemerintahan DI/TII. Menggunakan para pemuda dan kepalakepala daerah sebagai propagandis pendukung revolusi. Taktik gerilya dilancarkan, berbagai macam aktivitas yang telah dilakukan, aksi kekerasan, pembakaran, aksi sabotase, perampasan harta benda, serta perlawanan dari kaum adat turut mewarnai perjalanan gerakan DI/TII di Bulukumba. Dampak yang timbulkan oleh keberadaan DI/TII di Bulukumba menjadi kolektif memori dalam masyarakat, yakni hidup di masa DI/TII masyarakat diperhadapkan dua pilihan yaitu hidup atau mati.

Fatma, Z., 2018. [Wawancara] (3 Januari 2018).

Habi, 2018. [Wawancara] (24 Maret 2018).

Inventaris Arsip Khasanah Bulukumba , 1930-1960. No. $\operatorname{Reg} 88$, Makassar: Badan Perpustakaan dan Kearsipan Sulawesi Selatan.

Inventaris Arsip Propinsi Sulawesi, 19501960. No. Reg 331b, Makassar: Badan Perpustakaan dan Kearsipan Sulawesi Selatan.

Inventaris Arsip Propinsi Sulawesi, 19501960. No. Reg. 333, Makassar: Badan Perpustakaan dan Kearsipan Sulawesi Selatan.

Jarre, 2018. [Wawancara] (24 Maret 2018).

Jaya, K., 2018. [Wawancara] (3 Januari 2018).

Jupri, 2018. [Wawancara] (20 Maret 2018). 
JURNAL PATTINGALLOANG

(C)Jurusan Pendidikan Sejarah Fakultas Ilmu Sosial Universitas Negeri Makassar

Kementerian Penerangan, 1953. Republik

Indonesia Propinsi Sulawesi. s.l.:s.n.
Rohe, D., 2018. [Wawancara] (21 Maret 2018). 